\title{
HIDROLISIS RUMPUT LAUT EUCHEMA COTTONII MENGGUNAKAN ASAM SULFAT DAN KULTUR INAKTIF UNTUK PRODUKSI PREBIOTIK
}

\section{Hydrolize of Seaweeds Eucheumma cottonii Using Sulfuric Acid and Inactive Culture for Production of Prebiotics}

\author{
Vitta Rizky Permatasari ${ }^{1}$, Dwi Setyaningsih ${ }^{2}$, Liesbetini Haditjaroko ${ }^{3}$ \\ 1,3Jurusan Teknologi Industri Pertanian - Fakultas Teknologi Pertanian - Institut Pertanian Bogor \\ Jl. Dramaga - Kab. Bogor 16680 \\ ${ }^{2}$ Surfactant and Bioenergy Research Center - Institut Pertanian Bogor \\ Jl. Pajajaran No.1 Bogor 16144 \\ *Penulis Korespondensi: email: vitta.permata@gmail.com
}

\begin{abstract}
ABSTRAK
Produksi rumput laut di Indonesia pada tahun 2016 meningkat hampir 4 kali lipat dari tahun 2010. Nilai ini menunjukkan potensi rumput laut yang sangat besar. Jenis yang paling sering dimanfaatkan yaitu Eucheumma cottonii sebagai penghasil karagenan, yang berpotensi sebagai prebiotik karena mengandung galakto-oligosakarida. Tujuan dari penelitian ini yaitu mendapatkan perlakuan lanjut terhadap hidrolisat agar mendapatkan aktivitas prebiotik yang paling baik serta mengkarakterisasi sifat prebiotik dari hidrolisat. Tahapan penelitian meliputi pre hidrolisis, hidrolisis dengan campuran asam sulfat dan kultur inaktif, perlakuan lanjutan dengan 3 jenis (penyaringan, pengendapan, dan tanpa perlakuan), karakterisasi kimia dan mikrobiologis serta pengujian kadar galaktosa dengan HPLC. Hasil dari penelitian ketiga sampel jenis perlakuan, ternyata tanpa perlakuan mempunyai hasil yang paling baik dibandingkan kedua perlakuan yang lain, dengan nilai kadar gula reduksi sebesar $0.37 \%$, total gula $2.88 \%, \mathrm{pH} 4.95$, total asam $0.15 \%$, total BAL $62 \times 10^{7} \mathrm{CFU} / \mathrm{ml}$, kadar galaktosa dan GOS masing-masing sebesar $0.14 \%$ dan $1.18 \%$
\end{abstract}

Kata kunci : Eucheumma cottonii, Hidrolisis, Prebiotik

\begin{abstract}
Indonesia's seaweed production in 2016 increased almost 4-fold from 2010. This value indicates a great potential of the seaweed. The most widely used type is Eucheuma cottonii which utilized in carrageenan production. In addition, E. cottonii has potential as a prebiotic due to the galacto-oligosaccharides component. The purpose of this sudy was to determined the best types of treatment of hydrolisate for reached probiotic activity and characterized probiotic content of hydolisate. The preparation stage consists of pre-hydrolysis, hydrolysis using sulfuric acid and inactive culture, and followed by three different types of treatment (filtration, precipitation and without any treatment). The analytical stage consists of chemical and microbiological characterization, measured galactose using HPLC. The results showed that untreated samples had the best results compared with the other two treatments, with reduction sugar content $0.37 \%$, total sugar $2.88 \%$, pH $4.95 \%$, total acid $0.15 \%$, total BAL $62 \times 10^{7} \mathrm{CFL} / \mathrm{ml}$, galactose and GOS content are $0.14 \%$ and $1.18 \%$
\end{abstract}

Keywords : Eucheuma cottonii, Hydrolize, Prebiotic 


\section{PENDAHULUAN}

Total produksi rumput laut Indonesia pada tahun 2016 meningkat hampir 4 kali lipat dibandingkan tahun 2010 yaitu 3.9 juta ton (Kementerian Kelautan dan Perikanan, 2016). Angka tersebut menunjukkan potensi yang baik untuk pengembangan dan pemanfaatan rumput laut, khususnya jenis E. cottonii sebagai penghasil karagenan. Umumnya karagenan diperoleh dari ekstraksi beberapa jenis spesies rumput laut dengan menggunakan air atau larutan alkali (Winarno, 1996; Knudsen et al., 2017; Derkach et al., 2018), methyl ester dan kelompok piruvat (Van de Velde, 2012). Selain galaktosa dan sulfat, karagenan juga mengandung beberapa jenis karbohidrat, salah satunya jenis oligosakarida.

Oligosakarida merupakan jenis karbohidrat sederhana, jenis polisakarida berantai pendek (3-10 rantai glukosa) biasanya diperoleh dengan cara ekstraksi dari bahan alami, hidrolisis kimia polisakarida atau dengan sintesis kimia/enzimatis dari disakarida (Mussatto dan Mancilha, 2007). Berdasarkan beberapa penelitian terkait manfaat oligosakarida, senyawa ini dapat digolongkan sebagai prebiotik karena mampu menstimulasi berkembangnya metabolisme bakteri baik di dalam usus sehingga bermanfaat bagi kesehatan (Musatto dan Mancilha, 2007).

Ada beberapa metode untuk mendapatkan senyawa GOS (galakto oligosakarida) dari Eucheuma cottoni. Pada prinsipnya yaitu proses hidrolisis untuk menghidrolisa polisakarida menjadi gula sederhana, sehingga memudahkan proses fermentasi. Proses hidrolisis dapat dilakukan secara kimiawi maupun enzimatis (Rahim et al., 2014). Proses hidrolisis menggunakan asam mempunyai beberapa kelemahan, yaitu prosesnya panjang, perlu penanganan limbah asam, berpotensi korosi pada alat produksi, serta menghasilkan senyawa toksik yang menghambat pertumbuhan mikroorganisme pada proses fermentasi (Mota et al., 2018; Norberto et al., 2018). Oleh karena itu banyak peneliti yang beralih menggunakan enzim sebagai bahan hidrolisis karena senyawa penghambat pertumbuhan mikroba tidak terbentuk, sehingga produknya aman.

Menurut penelitian Meliawati (2015) dan Zhu dan Ning (2016), karagenan dapat dihidrolisis menjadi GOS dengan bantuan enzim kappa-karagenase yang diisolasi dari mikroba Vibrio algynoliticus. Berdasarkan pe- nelitian Ridho'ah (2016), ternyata hidrolisis enzimatis menghasilkan tekstur hidrolisat yang terlalu kental. Oleh karena itu penelitian ini menggunakan kombinasi asam sulfat $3 \%$ dan kultur vibrio yang telah diinaktivasi. Penggunaan kultur inaktif mempunyai derajat polimerisasi rendah, sehingga kandungan gulanya lebih mudah dimanfaatkan BAL untuk metabolisme jika dibandingkan dengan kultur yang aktif (Butscher et al., 2016; Dinda 2016; Bakheet et al., 2018).

Pengendapan karagenan dengan pelarut polar (alkohol) memiliki mutu yang paling baik, karena menghasilkan karagenan yang lebih murni dibandingkan non alkohol (Zainuddin, 2012; Meng et al., 2018). Beberapa jenis alkohol yang bisa digunakan sebagai pengendap karagenan yaitu metanol, etanol (Rahmawati, 2004; Sukhlaaied dan Riyajan, 2013; Meng et al., 2018; Sason dan Nussinovitch, 2018) dan isopropil alkohol (Hidayah et al., 2014). Metanol bersifat toksik, sehingga tidak diijinkan penggunaannya pada bahan pangan. Etanol juga pengendap yang baik, tetapi IPA lebih mudah didapatkan serta harganya lebih murah dibandingkan dengan etanol. Penelitian ini menggunakan IPA sebagai bahan pengendap.

Pemurnian enzim diperlukan guna meningkatkan aktivitas karagenase. Terdapat dua cara untuk memurnikannya yaitu dengan cara pengendapan dalam garam organik atau pelarut organik dan melalui membran. Pelarut organik yang digunakan pada penelitian ini adalah IPA dan membran yang dipakai yaitu kain saring 200 mesh. Penelitian ini menggunakan tiga perlakuan sampel yang berbeda. Pertama menggunakan metode penyaringan dengan kain saring. Sampel kedua diendapkan dengan IPA. Sampel ketiga digunakan sebagai kontrol, sehingga tanpa diberikan perlakuan. Ketiga sampel tersebut perlu diuji untuk mengetahui perlakuan yang paling baik.

\section{BAHAN DAN METODE}

\section{Bahan}

Bahan yang digunakan pada penelitian antara lain E. cottonii, asam dinitrosalisilat (DNS), akuades steril, asam sulfat 3\%, MRS broth, MRS agar, yeast extract, pepton, kultur BAL (Bifidobacterium longum) dan kultur vibrio yang telah diinaktivasi. 
Alat

Alat-alat yang digunakan pada penelitian ini antara lain laminar flow, cawan petri steril, mikropipet, oven, tabung reaksi, labu erlenmeyer, beaker glass, pembakar spirtus, botol alkohol, kain saring 200 mesh, corong vakum, timbangan digital, vortex, autoclave, inkubator, $\mathrm{pH}$ meter, lemari pendingin, spektrofotometer Hitachi U2900, High Performance Liquid Chromatography (HPLC), sonikator, sentrifus, pipet volumetrik, dan hotplate strirer.

\section{Metode}

a. Penelitian Pendahuluan (Pre-Hidrolisis)

Penelitian pendahuluan terdiri dari persiapan bahan baku berupa rumput laut serta membuat kultur inaktif untuk proses hidrolisis. Rumput laut segar yang telah direndam, dibilas dan dikeringkan kemudian dicacah dan dianalisa komponen kimiawinya berupa kadar air, kadar abu, lemak total, serat kasar, protein, dan karbohidrat. Pembuatan kultur inaktif memanfaatkan mikroba laut Vibrio alginolyticus yang ditumbuhkan pada media padat karagenan dan diinokulasi ke media starter cair, kemudian disentrifuse dan disonikasi pada suhu $4{ }^{\circ} \mathrm{C}$.

\section{b. Hidrolisis dengan Asam dan Kultur Inaktif}

Proses hidrolisis bertujuan untuk mengubah selulosa menjadi gula pereduksi dengan bantuan kombinasi asam sulfat 3\% dan kultur inaktif 10\% (v/v). Larutan kemudian diletakkan di waterbath pada suhu $30{ }^{\circ} \mathrm{C}$ selama 48 jam.

\section{c. Perlakuan Lanjutan}

Langkah selanjutnya, hidrolisat dibagi menjadi tiga macam jenis perlakuan, yaitu disaring dengan kain saring (200 mesh) yang diletakkan diatas corong vakum. Hal ini dilakukan untuk memaksimalkan hasil supernatan Eucheuma cottonii. Tujuan dari proses penyaringan adalah untuk mendapatkan fase terlarut saja, sehingga padatan yang lebih besar tidak ikut masuk ke dalamnya. Perlakuan kedua diendapkan dengan isopropil alkohol sebanyak $80 \%$ (v/v). Tujuannya untuk meningkatkan kemurnian karagenan dan perlakuan ketiga tanpa diberi perlakuan sebagai kontrol.

\section{d. Karakterisasi secara kimia dan mikrobiologi \\ Hidrolisat yang telah dibagi menjadi tiga macam perlakuan kemudian diuji kandungan}

hidrolisatnya (kimia), antara lain gula reduksi, total gula, pH, serta total asam. Uji mikrobiologi dilakukan dengan menghitung total BAL. Semua pengujian tersebut dilakukan sebelum dan sesudah proses fermentasi. Selanjutnya, menganalisa kadar galaktosa dengan HPLC. Berdasarkan ketiga jenis perlakuan kemudian dipilih dua perlakuan yang paling baik dari segi kimiawi dan mikrobiologisnya untuk dilakukan pengujian lanjut. Hasil analisa menunjukkan bahwa perlakuan penyaringan dan tanpa perlakuan mempunyai nilai yang lebih baik dibandingkan dengan pengendapan.

\section{e. Analisa Data}

Pengolahan data dilakukan dengan metode Rancangan Acak Lengkap menggunakan satu faktor dan tiga taraf. Percobaan dilakukan sebanyak dua kali dengan masing-masing pengukuran diulang sebanyak tiga kali. Apabila ada salah satu perlakuan atau interaksinya berpengaruh nyata maka analisis dilanjutkan dengan uji Duncan. Parameter yang diuji diantaranya gula reduksi, total gula, pH (Dinda, 2016), serta total asam dan total BAL (Ridho'ah, 2016).

\section{HASIL DAN PEMBAHASAN}

\section{Komposisi Eucheuma cottonii dan Karakteristik Hidrolisat \\ Rumput laut yang akan diuji kand-} ungan kimiawinya merupakan rumput laut yang telah kering. Komposisi kimiawi yang diuji meliputi kadar air, kadar abu, kadar lemak total, kadar serat kasar, kadar protein, dan karbohidrat. Pengujian ini bertujuan untuk memperoleh data kasar tentang komposisi kimia bahan baku yang diuji. Hasil pengujian proksimat dan perbandingan dengan karaginan komersial dan standar FAO ditunjukkan pada Tabel 1.

Pada Tabel 1 dapat disimpulkan bahwa hasil pengujian bahan baku secara keseluruhan memenuhi standar karagenan komersial maupun standar yang ditetapkan oleh FAO. Penelitian ini menggunakan metode campuran asam sulfat dan kultur Vibrio alginolyticus yang telah diinaktivasi dengan metode sonikasi. Proses sonikasi bertujuan untuk memecah dinding sel dan mengeluarkan enzim intraselular pada kultur Vibrio alginolyticus. Pemecahan dinding sel dengan 
metode sonikasi terjadi akibat penggunaan frekuensi gelombang suara ultrasonik yang besar. Gelombang suara menyebabkan terjadinya proses kavitasi yaitu terbentuknya gelembung gas yang bergerak dengan kecepatan tinggi sehingga terbentuk energi mekanik yang menyebabkan dinding sel pecah (Loo et al., 1950; Chaplin dan Buckle 1990; Webster et al., 1978).

Selanjutnya, hidrolisat difermentasi dengan ditambahkan $10 \%$ (v/v) inokulum probiotik Bifidobacterium longum. Pada tahap ini, hasil fermentasi ditumbuhkan dengan $5 \%$ inokulum Bifidobacterium longum yang berumur 4 jam untuk mengetahui karakteristik fisiko kimia dan pertumbuhan BAL dalam media hidrolisat terpilih. Adapun banyaknya inokulum yang ditambahkan serta umur inokulum telah ditentukan oleh penelitian sebelumya (Zelvi et al., 2016). Rendemen dihitung berdasarkan jumlah hidrolisat yang akan diuji secara mikrobiologis dan kimiawi.

\section{Perbandingan Karakteristik Hidrolisat Hasil Perlakuan Lanjut Sebelum dan Sesudah Fermentasi}

Tujuan dari perlakuan lanjut berupa penyaringan dan pengendapan adalah untuk memperoleh fase terlarut, sehingga karagenan dan GOS yang didapatkan lebih murni. Grafik hasil pengujian gula reduksi, total gula, $\mathrm{pH}$, total asam, dan total BAL dari ketiga perlakuan ditunjukkan pada Gambar 1-5.

\section{Gula Reduksi}

Berdasarkan penelitian yang telah dilakukan, selama proses fermentasi terjadi penurunan jumlah gula reduksi. Hal ini disebabkan karena bakteri menggunakan gula sederhana yang ada pada hasil hidrolisis. Sesuai dengan pernyataan Putri dan Sukandar (2008), bahwa selama proses fermentasi kadar gula reduksi cenderung menurun karena gula yang terdapat dalam media digunakan sebagai sumber karbon bagi sel bakteri untuk mensintesis energi melalui proses fermentasi. Kandungan gula reduksi digunakan oleh bakteri probiotik sebagai sumber energi pada proses fermentasi. Tingginya gula reduksi diduga karena proses hidrolisis gula kompleks menjadi gula sederhana selama fermentasi masih terjadi. Pada ketiga jenis perlakuan, hidrolisat yang mendapatkan perlakuan baik dengan penyaringan maupun pengendapan mempunyai nilai gula reduksi yang lebih tinggi daripada hidrolisat tanpa perlakuan. Hal tersebut karena kedua perlakuan dapat memisahkan glukosa dan bahan tersuspensi lain (zat organik non glukosa), sehingga diperoleh kadar gula dengan kemurnian yang lebih tinggi dibandingkan tanpa perlakuan. Dengan kata lain, pada perlakuan penyaringan, bakteri paling banyak mengonsumsi gula untuk proses metabolismenya. Hal ini disebabkan pada pengendapan, bahan non glukosa dan bahan tersuspensi lain yang ternyata lebih banyak dari glukosa, sehingga BAL kurang maksimal dalam proses metabolismenya. Pada proses penyaringan, yang difermentasi adalah fase terlarut yang lebih banyak mengandung gula. Hasil analisa statistik menunjukkan bahwa perlakuan dengan penyaringan berbeda nyata dengan pengendapan dan tanpa perlakuan.

\section{Total Gula}

Setelah fermentasi selama 48 jam pada ketiga perlakuan menunjukkan reaksi yang berbeda. Penerapan perlakuan di proses penyaringan dan tanpa perlakuan mengalami penurunan, sedangkan pada perlakuan pengendapan mengalami kenaikan. Nilai total gula yang mengalami kenaikan, hal ini membuktikan bahwa hidrolisis menggunakan campuran asam dan enzim inaktif terbukti dapat menghasilkan gula (oligosakarida) pada proses hidrolisis selama $48 \mathrm{jam}$. Pada dua perlakuan yang mengalami penurunan nilai total gula, hal tersebut dapat diartikan bahwa konversi gula kompleks menjadi gula sederhana terjadi secara efektif. Selain itu, pada perlakuan penyaringan, jenis karbohidrat yang tidak larut air sudah dikeluarkan, hal tersebut yang menjadikan nilai total gula menjadi turun. Peningkatan kandungan gula selama proses fermentasi dapat disebabkan oleh Bifidobacterium longum yang memiliki aktivitas dalam mendegradasi polisakarida menjadi gula sederhana. Bifidobacterium $\mathrm{sp}$ tergolong jenis bakteri yang dapat menghasilkan enzim hidrolase glikosida. Enzim tersebut mempunyai kemampuan dalam mendegradasi polisakarida dan oligosakarida menjadi gula sederhana yang bermanfaat untuk reaksi pada proses fermentasi (Van den Broek et al., 2008). Semakin banyak gula yang dihasilkan, menunjukkan efektivitas proses hidrolisis dalam mengekstrak E.cottonii. Kandungan gula kompleks ini dapat digunakan BAL untuk proses metabolisme selama proses fermentasi berlangsung. 
Aktivitas bakteri dalam menghasilkan asam laktat dapat meningkat dengan tingginya ketersediaan gula dalam media pertumbuhannya. Berdasarkan hasil analisa statistik, perlakuan penyaringan dan pengendapan berbeda nyata dengan tanpa perlakuan.

\section{3. $\mathrm{pH}$}

Pada ketiga sampel perlakuan didapatkan $\mathrm{pH}$ tertinggi ada pada sampel dengan perlakuan pengendapan. Hal ini disebabkan karena adanya penambahan isopropanol yang bersifat asam. Kisaran $\mathrm{pH}$ yang terbentuk setelah fermentasi berada dalam kisaran $\mathrm{pH}$ 4.8-6.2. Nilai $\mathrm{pH}$ tersebut mengindikasikan bahwa bakteri yang ditemukan dalam hidrolisat Eucheuma cottonii adalah kelompok bakteri asam laktat. Hal ini sesuai dengan hasil penelitian Rahayu (2010) bahwa derajat keasaman optimum untuk pertumbuhan bakteri asam laktat berkisar 3.8-8.0. Hal serupa juga disampaikan oleh Legowo et al. (2009), bahwa selama proses fermentasi terjadi penguraian laktosa yang dipecah menjadi glukosa dan galaktosa oleh BAL. Selanjutnya, glukosa akan diubah menjadi asam laktat dan beberapa asam organik lainnya. Seiring berjalannya proses fermentasi selama 48 jam selain ditandai dengan meningkatnya total BAL, juga adanya nilai $\mathrm{pH}$ yang cenderung menurun dan keasaman yang cenderung meningkat, tetapi tidak berpengaruh nyata. Pemecahan gula dalam sel BAL akan menghasilkan energi untuk aktivitas bakteri probiotik sehingga dihasilkan asam laktat. Pembentukan asam laktat tersebut akan menurunkan nilai $\mathrm{pH}$ dan menghasilkan rasa asam pada produk yang dihasilkan. Berdasarkan analisa statistik, perlakuan penyaringan tidak berbeda nyata dengan tanpa perlakuan, tetapi berbeda nyata dengan pengendapan.

\section{Total Asam}

Berdasarkan hasil penelitian, nilai total asam semakin meningkat seiring berlangsungnya proses fermentasi. Dengan kata lain, nilai total asam berbanding terbalik dengan nilai $\mathrm{pH}$ yang semakin menurun selama proses fermentasi. Total asam yang terbentuk diasumsikan sebagai jumlah asam laktat yang merupakan hasil dari metabolit BAL yang ditambahkan. Meskipun penurunan $\mathrm{pH}$ tidak terlalu signifikan, akan tetapi total asam masih tetap terbentuk. Menurut SNI 2981-2009 tentang syarat mutu yoghurt, yoghurt memiliki nilai total asam $0.5-2.0 \%$, sedangkan total asam pada hidrolisat rumput laut hanya berkisar 0.12 sampai 0.15 atau tergolong rendah. Menurut Kailasapathy et al. (2011), Bifidobacterium longum merupakan golongan BAL heterofermentatif, dimana pada proses fermentasinya tidak menghasilkan asam laktat sebagai produk tunggal, tetapi menghasilkan asam organik lainnya, etanol dan sejumlah $\mathrm{CO}_{2}$. Hal inilah yang menjadi salah satu penyebab jumlah total asam pada hidrolisat rumput laut yang rendah. Berdasarkan analisa statistik, ketiga perlakuan tidak berbeda nyata satu sama lain.

\section{Total BAL}

Berdasarkan hasil penelitian pada histogram yang ditunjukkan pada Gambar 5, terlihat bahwa ketiga perlakuan berbeda mengalami peningkatan jumlah bakteri. Peningkatan jumlah mikroba tersebut disebabkan Bifidobacterium longum mengalami pertumbuhan berupa pertambahan jumlah sel. Mikroba memanfaatkan nutrisi (karbohidrat) yang telah dipecah menjadi gula sederhana untuk melakukan aktifitas pertumbuhan sehingga pertumbuhannya meningkat. Peningkatan total BAL selama fermentasi disebabkan karena bakteri mempunyai $\mathrm{pH}$ yang optimal untuk menghasilkan asam laktat dari perombakan gula dan protein menjadi komponen yang lebih sederhana, seperti asam organik, asam laktat, $\mathrm{CO}_{2}, \mathrm{H}_{2} \mathrm{O}$, dan energi (Oliveira et al., 2011; Kumalaningsih et al.,. 2014; Soccol et al., 2017). Setelah masa inkubasi selama 72 jam, jumlah BAL yang paling banyak terdapat pada sampel ketiga (tanpa penyaringan dan pengendapan). Hal ini terjadi dikarenakan jumlah nutrisi pada sampel ketiga lebih banyak dibandingkan kedua sampel yang lain. Hal ini diduga karena nutrisi yang berupa gula sederhana dari hidrolisat rumput laut sebagian ikut mengendap pada saat proses pengendapan dan penyaringan, sedangkan pada sampel ketiga nutrisi tersebut tetap utuh, sehingga bakteri lebih aktif tumbuh selama proses inkubasi. Berdasarkan analisa statistik, perlakuan dan penyaringan dan pengendapan berbeda nyata dengan tanpa perlakuan.

\section{c. Analisa Kadar Galaktosa}

Karagenan merupakan polisakarida yang linier atau lurus, dan merupakan molekul galaktan dengan unit-unit utamanya 
Jurnal Teknologi Pertanian Vol. 19 No. 2 [Agustus 2018] 85-94

Hidrolisis Rumput Laut Eucheuma cottonii Menggunakan Asam Sulfat [Permatasari dkk]

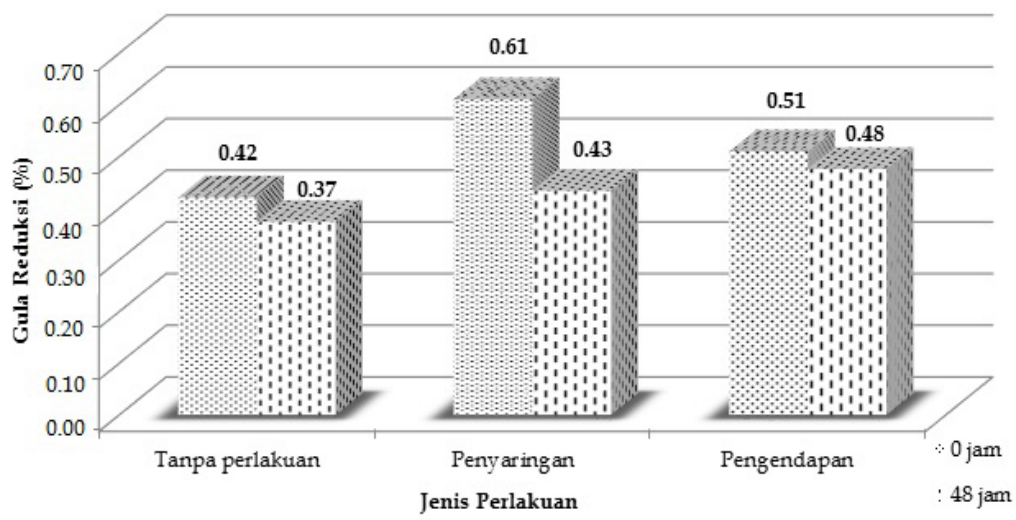

Gambar 1. Kadar gula sebelum dan sesudah fermentasi 48 jam

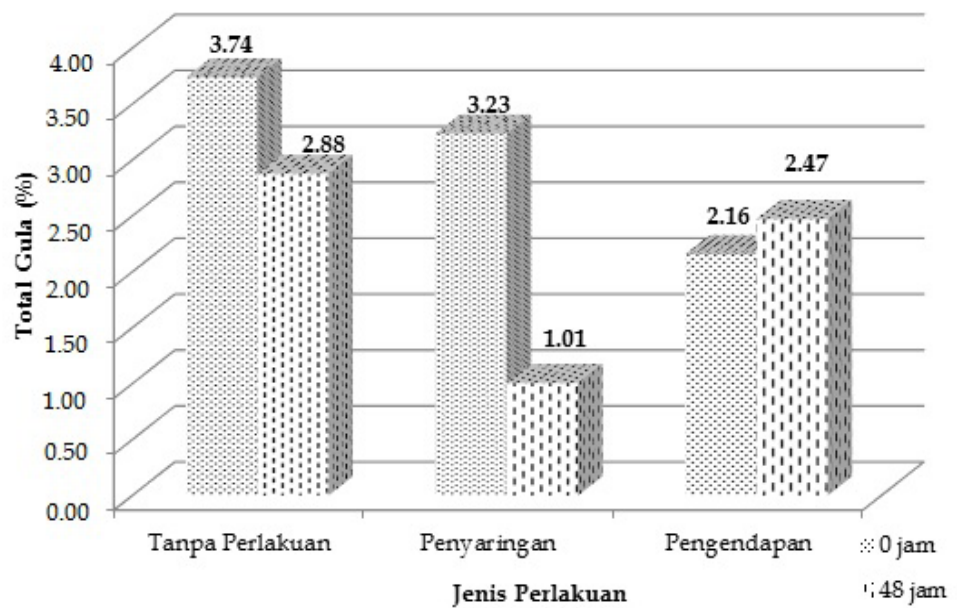

Gambar 2. Total gula sebelum dan sesudah fermentasi 48 jam

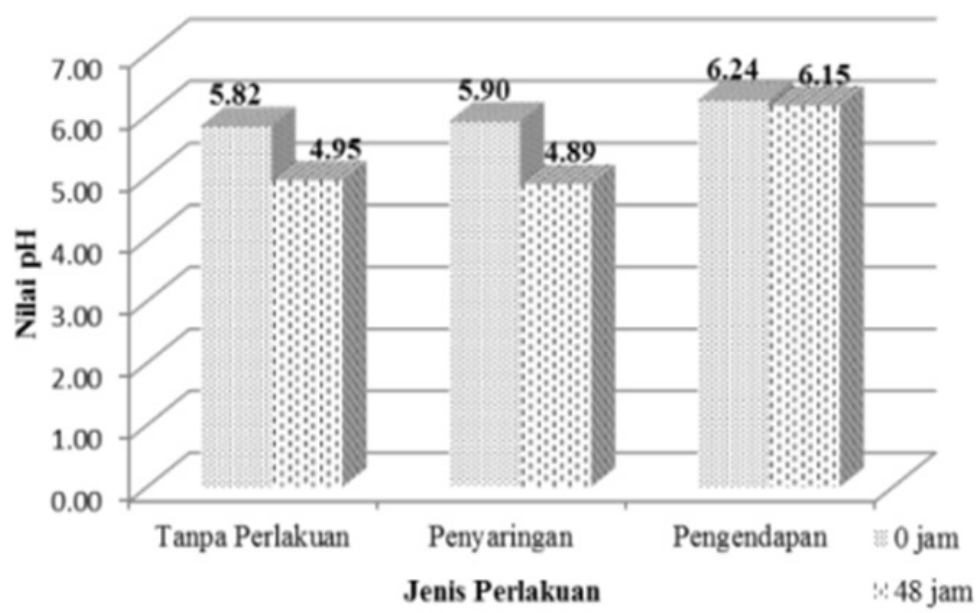

Gambar 3. Nilai pH sebelum dan sesudah fermentasi 48 jam 


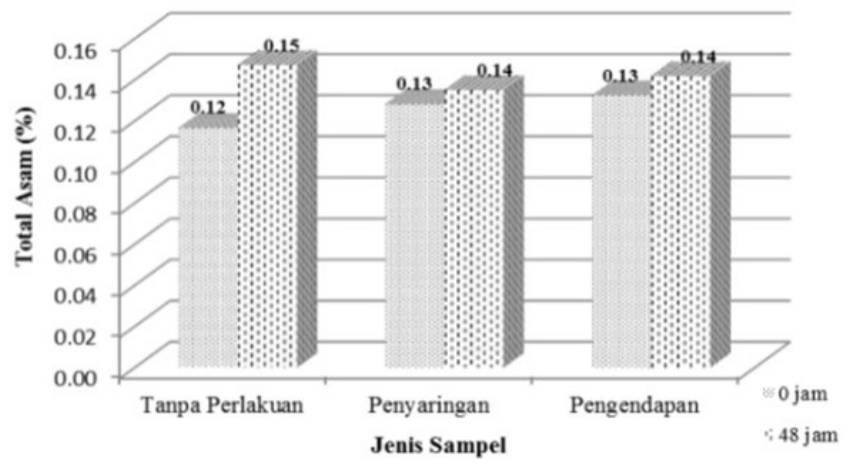

Gambar 4. Total asam sebelum dan sesudah fermentasi 48 jam

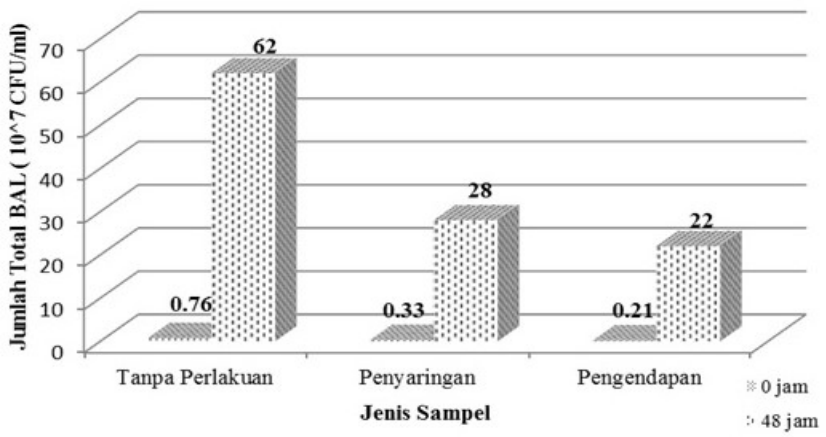

Gambar 5. Total Bifidobacterium longum sebelum dan sesudah fermentasi

Tabel 1. Komposisi kimia rumput laut (\% berat kering)

\begin{tabular}{lccc}
\hline Parameter Uji & $\begin{array}{c}\text { Hasil Uji } \\
\mathbf{( \% )}\end{array}$ & $\begin{array}{c}\text { Karaginan Komersial } \\
(\mathbf{\%})^{*}\end{array}$ & $\begin{array}{c}\text { Karaginan Standar FAO } \\
(\mathbf{\%})^{*}\end{array}$ \\
\hline Air & 11.20 & 14.34 & Maks 12 \\
Abu & 15.49 & $15-40$ & $18-40$ \\
Lemak Total & 0.33 & 1.78 & - \\
Serat Kasar & 6.39 & Maks 7.02 & - \\
Protein & 7.12 & 2.80 & - \\
Karbohidrat & 65.86 & Maks 68.48 & - \\
\hline
\end{tabular}

* Sumber : Københavns, 1978

Tabel 2. Perbandingan kadar galaktosa pada hidrolisat Eucheuma cottonii

\begin{tabular}{lcc}
\hline Jenis Perlakuan & Waktu Retensi & Kadar Galaktosa (\%) \\
\hline Penyaringan & 9.024 & 0.72 \\
Pengendapan & 8.294 & 0.28 \\
Tanpa perlakuan & 8.881 & 0.14 \\
\hline
\end{tabular}


adalah galaktosa. Beberapa penelitian sebelumnya telah menggunakan HPLC untuk menganalisa kadar gula, terutama galaktosa. Pada keempat jenis gula yang terdapat pada Eucheumma sp, komponen gula tertinggi adalah D-galaktosa, sedangkan komponen gula terendah adalah glukosa (Machmud et al., 2013; Fakhrudin et al., 2014; Arsianti et al., 2018). Waktu retensi dan luas area puncak yang menjadi acuan untuk melihat apakah pada sampel yang diiject terdapat senyawa yang diinginkan sesuai dengan standar, yaitu galaktosa. Hasil analisa dengan HPLC ditunjukkan pada Tabel 2.

Berdasarkan Tabel 2, diperoleh hasil bahwa kadar galaktosa tertinggi terdapat pada perlakuan 1 (penyaringan) yaitu sebesar $0.7246 \%$ dan kadar terendah pada tanpa perlakuan yaitu sebesar $0.1359 \%$. Nilai tersebut sesuai dengan kadar gula reduksi dan total gula pada pengujian sebelumnya dimana perlakuan penyaringan juga mempunyai nilai paling tinggi. Hal tersebut semakin membuktikan bahwa dengan penyaringan, nutrisi terutama gula lebih pekat dan murni dibandingkan dengan diendapkan maupun tanpa perlakuan.

\section{SIMPULAN}

Hasil penelitian menunjukkan bahwa dari ketiga sampel jenis perlakuan, hidrolisat tanpa perlakuan mempunyai hasil yang paling baik dibandingkan kedua perlakuan yang lain, dengan nilai kadar gula reduksi sebesar $0.37 \%$, total gula $2.88 \%, \mathrm{pH} 4.95$, total asam $0.15 \%$, total BAL $62 \times 10^{7} \mathrm{CFU} / \mathrm{ml}$, kadar galaktosa dan GOS masing-masing sebesar $0.14 \%$ dan $1.18 \%$.

\section{DAFTAR PUSTAKA}

Arsianti, A, Aziza, Y, A, N, Kurniasari, K, D, Mandasari, B, K, D, Masita, R, Zulfa, F, R, Dewi, M, K, Zagloel, C, R, Z, Azizah, N, N, Putrianingsih, R. 2018. Phytochemical test and cytotoxic activity of macroalgae Eucheuma cottonii against Cervical HeLa cells. Pharmacogn. J. 10(5):1012-1017

Bakheet, B, Islam, Md, A, Beardall, J, Zhang, X, McCarthy, D. 2018. Effective electrochemical inactivation of Microcystis aeruginosa and degradation of microcystins via a novel solid polymer electrolyte sandwich. Chemical Engineering Journal. 350:616-626

Butscher, D, Loon, H, V, Waskow, A, Von Rohr, P, R, Schuppler, M. 2016. Plasma inactivation of microorganisms on sprout seeds in a dielectric barrier discharge. International Journal of Food Microbiology. 238:222-232

Chaplin, MF, Buckle, C. 1990. Enzyme Technology. Cambridge University Press. UK

Derkach, S, R, Voron'ko, N, G, Kuchina, Y, A, Kolotova, D, S, Gordeeva, A, M, Faizullin, D, A, Gusev, Y, A, Maksakova, O, N. 2018. Molecular structure and properties of $\mathrm{\kappa}$-carrageenan-gelatin gels. Carbohydrate Polymers. 197:66-74

Dinda, S. 2016. Hidrolisis Eucheuma cottonii Menggunakan Enzim dari Vibrio Alginolyticus untuk Menghasilkan Hidrolisat yang Bersifat Prebiotik. Skripsi. IPB. Bogor

Fakhrudin, J, Setyaningsih, D, Rahayuningsih, M. 2014. Bioethanol production from seaweed Eucheuma cottonii by neutralization and detoxification of acidic catalyzed hydrolysate. International Journal of Environmental Science and Development. 5(5):455-458

Hidayah, N, Widyastuti, S, Rosmilawati, Saptono, Handito, D. 2014. Pengaruh konsentrasi isopropil alkohol terhadap sifat mikrobiologis dan organoleptik karaginan Eucheuma cottonii. Agroteksos. 24(3):153-158

Kailasapathy, K, Champagne C, Moore, S. 2011. Synbiotic Yoghurt - A Smart Gut Food. Nova Science Publishers Inc. New York

Kementerian Kelautan dan Perikanan. 2016. Informasi Kelautan dan Perikanan. Dilihat 12 April 2018. < http:/ / statistik.kkp.go.id/sidatik-dev/Publikasi/ src/informasikpjanuari2016.pdf>

Knudsen, R, N, Ale, M, T, Ajalloueian, F, Yu, L, Meyer, A, S. 2017. Rheological properties of agar and carrageenan from Ghanaian red seaweeds. Food Hydrocolloids. 63:50-58

Københavns, P. 1978. Carrageenan. Lillekensved. Denmark

Kumalaningsih, S, Wignyanto, Permatasari, V, R, Triyono, A. 2014. Pengaruh jenis mikroorganisme dan $\mathrm{pH}$ terhadap kualitas minuman probiotik dari ampas Tahu. 
Dilihat 12 April 2018. < http://skripsitipftp.staff.ub.ac.id/files/2014/11/2.JURNAL-A.-Triyono.pdf >

Legowo, AM, Kusrahayu, Mulyani, S. 2009. Ilmu dan Teknologi Pengolahan Susu. Universitas Diponegoro. Semarang

Loo, C, C, Slatter, W, L, Powell, R, W. 1950. A study of the cavitation effect in the homogenization of dairy products. Journal of Dairy Science. 33(10):692-702

Machmud, M, N, Fuadi, Z, Fadi, F, Kokarkin, C. 2013. Alternative fiber sources from Gracilaria Sp and Eucheuma Cottonii for Papermaking. Internat. J. Sci. Eng. 6(1):1-10

Meliawati, T. 2015. Karakterisasi Enzim Karagenase dari Isolat Mikroba Laut untuk Hidrolisis Eucheuma cottonii. Sripsi. IPB. Bogor

Meng, F, Zhou, Y, Liu, J, Wu, J, Wang, G, Li, R, Zhang, Y. 2018. Thermal decomposition behaviors and kinetics of carrageenan-poly vinyl alcohol biocomposite film. Carbohydrate Polymers. 201:96-104

Mota, M, J, Lopes, R, P, Sousa, S, Gomes, A, M, Delgadillo, I, Saraiva, J, A. 2018. Lactobacillus reuteri growth and fermentation under high pressure towards the production of 1,3-propanediol. Food Research International. 113:424-432

Mussatto, S, I, Mancilha, I, M. 2007. Nondigestible oligosaccharides : a review. Carbohydrate Polymers. 68(3):587-597

Norberto, A, P, Marmentini, R, P, Carvalho, $\mathrm{P}, \mathrm{H}$, Campagnollo, F, B, Takeda, H, H, Alberte, T, M, Rocha, R, S, Cruz, A, G, Alvarenga, V, O, Sant'ana, A, S. 2018. Impact of partial and total replacement of milk by water-soluble soybean extract on fermentation and growth parameters of kefir microorganisms. LWT. 93:491-498

Oliveira, M, E, S, Panyoja, L, Duarte, W, F, Collela, C, F, Valarelli, Schwan, R, F, Dias, D, R. 2011. Fruit wine produced from cagaita (Eugenia dysenterica DC) by both free and immobilised yeast cell fermentation. Food Research International. 44(7):2391-2400

Putri, L, S, E, Sukandar, D. 2008. Konversi pati ganyong (Canna edulis Ker.) menjadi bioetanol melalui hidrolisis asam dan fermentasi. Biodiversitas. 9(2):112-116

Sason, G, Nussinovitch, A. 2018. Characterization of K-carrageenan gels immersed in ethanol solutions. Food Hydrocolloids. 79:136-144
SNI. 2009. Yoghurt. Dilihat 20 Juli 2018. <https:// www.scribd.com/document/354563676/ SNI-2981-2009-Yogurt-pdf>

Soccol, C, R, da Costa, E, S, F, Letti, L, A, J, Karp, S, G, Woiciechowski, A, L, Vandenberghe, L, P, S. 2017. Recent developments and innovations in solid state fermentation. Biotechnology Research and Innovation. 1(1):52-71

Sukhlaaied, W, Riyajan, S. 2013. Synthesis and properties of carrageenan grafted copolymer with poly(vinyl alcohol). Carbohydrate Polymers. 98:677-685

Rahayu, K. 2010. Mikrobiologi Pangan. PAU Pangan dan Gizi. Yogyakarta

Rahim, A, F, Wasoh, H, Zakaria, M, R, Ariff, A, Kapri, R, Ramli, N, Ling, L. 2014. Production of high yield sugars from Kappaphycus alvarezii using combined methods of chemical and enzymatic hydrolysis. Food Hydrocolloids. 42(2):309-315

Rahmawati, D. 2004. Mempelajari Aktivitas Antioksidan dan Antimikroba Ekstrak Antarasa (Litsea cubeba) dan Aplikasinya Sebagai Pengawet Alami Pada Bahan Pangan. Skripsi. IPB. Bogor

Ridho'ah, T. 2016. Karakteristik probiotik Bifidobacterium longum dan Lactobacillus casei pada hidrolisat Eucheuma cottonii. Skripsi. IPB. Bogor

Sason, G, Nussinovitch, A. 2018. Characterization of $\mathrm{k}$-carrageenan gels immersed in ethanol solutions. Food Hydrocolloids. 79:136-144

Van den Broek, L, A, M, Hinz, S, W, A, Beldman, G, Vincken, J, P, Voragen, A, G, J. Bifidobacterium carbohydrases-their role in breakdown and synthesis of (potential) prebiotics. 2008. Molecular Nutrition Food Research. 52(1):146-163

Van de Velde, F, Knutsen, S, H, Usov, A, I, Romella, H, S, Cerezo, A, S. 2002. ${ }^{1} \mathrm{H}$ and ${ }^{13} \mathrm{C}$ high resolution NMR spectoscopy of carrageenans: aplication in research and industry. Trends in Food Science \& Technology. 13(3):73-92

Winarno, FG. 1996. Teknologi Pengolahan Rumput Laut. Gramedia Pustaka Utama. Jakarta

Webster, D, F, Pond, J, B, Dyson, M, Harvey, W. 1978. The role of cavitation in the in vitro stimulation of protein synthesis in human fibroblasts by ultrasound. Ultrasound in Medicine \& Biology. 4(4):343-351 
Jurnal Teknologi Pertanian Vol. 19 No. 2 [Agustus 2018] 85-94

Hidrolisis Rumput Laut Eucheuma cottonii Menggunakan Asam Sulfat [Permatasari dkk]

Zainudin, 2012. Teknologi Pengolahan Rumput Laut. Pustaka Sinar Harapan. Jakarta

Zelvi, M, Suryani, A, Setyaningsih, D. 2016. Hidrolisis Eucheuma cottonii dengan enzim k-karagenase dalam menghasilkan gula reduksi untuk produksi bioethanol. Jurnal Teknologi Industri Pertanian. 27(1):33-42

Zhu, B, Ning, L. 2016. Purification and characterization of a new $\mathrm{k}$-carrageenase from the marine bacterium Vibrio sp. NJ-2. J. Microbiol. Biotechnol. 26(2):255262 